\title{
PENENTUAN PATOTIPE DAN KERAGAMAN GENETIK Xanthomonas oryzae pv. oryzae PADA TANAMAN PADI DI WILAYAH KARESIDENAN BANYUMAS
}

\author{
Heru Adi Djatmiko, Budi Prakoso \& Nur Prihatiningsih \\ Fakultas Pertanian Universitas Jenderal Soedirman, Purwokerto \\ Jl. dr. Suparno Karangwangal Purwokerto \\ E-mail:heru_adi@yahoo.com
}

\begin{abstract}
Identification of pathotype and genetic diversity of Xanthomonas oryzae pv. oryzae on rice in Karesidenan Banyumas area. One of the major diseases of rice paddy fields in Indonesia and the Asian countries is bacterial leaf blight or kresek caused by X. oryzae pv. oryzae (Xoo). Losses caused by the disease in Indonesia reached 70-80\%, in India reached 74-81\%, and Japan reached 20-50\%, thus causing great losses in the economy. The objectives of that research were: 1) Characterize Xoo from Karesidenan Banyumas; 2) To study of the amount of damage and AUDPC (the area under disease progress curve) of bacterial leaf blight disease at Karesidenan Banyumas; 3) To obtain of Xoo pathotype by using the test varieties; 4) To obtaining genetic diversity of Xoo that found in Banjarnegara, Purbalingga, Banyumas, Cilacap dan Kebumen region. Research was carried out in several stages: isolation and characterization of Xoo from Barlingmascakeb region, testing of Xoo with five varieties testing, assesment of disease intensity of bacterial leaf blight and AUDPC in the field, and testing the genetic diversity of Xoo. The results showed that pathogen of bacterial blight on rice is Xoo characterized yellow colour of colonies on SPA medium, negative gram reaction, catalase positive, oxidase negative, negative growth at $0.1 \% \mathrm{TZC}$, negative starch hydrolisis , and resistance to $0.001 \% \mathrm{Cu}\left(\mathrm{NO}_{3}\right)_{2}$ positive. Xoo pathotype isolats found in Banjarnegara was pathotype $\mathrm{X}$, Cilacap were pathotype I and II and Purbalingga was pathotype II. Eighteen of Xoo from Karesidenan Banyumas (Banjarnegara, Purbalingga, Banyumas, Cilacap and Kebumen) of RAPD differ one from the others.
\end{abstract}

Key words: genetic diversity, pathotype, rice, X. oryzae pv. oryzae

\begin{abstract}
ABSTRAK
Penentuan patotipe dan keragaman genetik Xanthomonas oryzae pv. oryzae pada tanaman padi di wilayah Karesidenan Banyumas. Salah satu penyakit utama padi sawah di Indonesia dan negara Asia adalah hawar daun bakteri atau kresek yang disebabkan oleh Xanthomonas oryzae pv. oryzae (Xoo). Kehilangan yang diakibatkan oleh penyakit tersebut di Indonesia mencapai $70-80 \%$, di India mencapai $74-81 \%$ dan Jepang mencapai $20-50 \%$, sehingga menyebabkan kerugian yang besar secara ekonomi. Tujuan penelitian yaitu: 1) Mengkarakterisasi Xoo dari wilayah Banjarnegara, Purbalingga, Banyumas, Cilacap dan Kebumen; 2) Mengkaji besarnya kerusakan dan AUDPC (the area under disease progress curve) penyakit hawar daun bakteri di wilayah Banjarnegara, Purbalingga, Banyumas, Cilacap dan Kebumen; 3) Mendapatkan patotipe Xoo dengan menggunakan varietas uji; 4) Mendapatkan keragaman genetik Xoo yang ditemukan di wilayah Banjarnegara, Purbalingga, Banyumas, Cilacap dan Kebumen. Penelitian dilaksanakan dalam beberapa tahap yaitu isolasi dan karakterisasi Xoo dari wilayah Barlingmascakeb, pengujian Xoo dengan 5 varietas uji, penilaian intensitas penyakit hawar daun bakteri dan AUDPC di lapangan dan pengujian keragaman genetik Xoo. Hasil penelitian menunjukkan bahwa penyebab penyakit hawar daun bakteri pada tanaman padi adalah Xoo dengan ciri warna koloni kuning pada medium SPA, reaksi gram negatif, katalase positif, oksidase negatif, pertumbuhan pada $0,1 \%$ TZC negatif, hidrolisis pati negatif dan ketahanan terhadap $0,001 \% \mathrm{Cu}\left(\mathrm{NO}_{3}\right)_{2}$ positif. Patotipe Xoo yang ditemukan di Kabupaten Banjarnegara yaitu patotipe X, Cilacap yaitu patotipe I dan II, dan Purbalingga yaitu patotipe II. Delapan belas isolat Xoo yang berasal dari Karesidenan Banyumas (Banjarnegara, Purbalingga, Banyumas, Cilacap dan Kebumen) mempunyai genetik berbeda berdasarkan pada pola pita DNA hasil dari RAPD berbeda satu dengan lainnya.
\end{abstract}

Kata kunci: keragaman genetic, padi, patotipe, X. oryzae pv. oryzae 


\section{PENDAHULUAN}

Padi merupakan komoditas yang sangat penting karena berasnya menjadi bahan makanan pokok penduduk Indonesia (Abdullah, 2002; Husodo, 2004). Beras menyumbangkan $60-80 \%$ kalori dan $45-55 \%$ protein untuk pemenuhan gizi penduduk Indonesia (Abdullah, 2002). Menurut Papanek (2005), nilai gizi yang diperlukan oleh setiap orang dewasa adalah 1821 kalori yang apabila disetarakan dengan beras, maka setiap hari diperlukan beras sebanyak $0,88 \mathrm{~kg}$. Oleh karena itu, perlu produksi padi yang berkesinambungan. Seiring dengan pertambahan penduduk Indonesia maka produksi padi harus selalu ditingkatkan.

Produksi padi tahun 2006 sebesar 54,66 juta ton Gabah Kering Giling (GKG). Produksi padi tahun 2006 meningkat didasarkan pada kenaikan luas panen sekitar 16 juta hektar $(0,13 \%)$ dan juga peningkatan produktivitas sebesar $0,37 \mathrm{kw} \mathrm{ha}^{-1}(0,81 \%)$. Peningkatan luas panen terutama terjadi di Luar Jawa sebanyak 14 ribu ha $(0,23 \%)$, sedangkan di Jawa hanya bertambah sekitar 2 ribu ha $(0,03 \%)$ (BPS, 2006). BPS (2008) memperkirakan produksi padi 2008 sebanyak 59,8 juta ton atau naik 4,8\% dibandingkan dengan tahun 2007 yang mencapai 57,2 juta ton gabah kering giling (GKG) atau setara 2,7 juta ton GKG. Kenaikan produksi diperkirakan terjadi karena peningkatan luas panen sebesar 237 ribu ha atau 1,96 lebih luas dari panen 2007 (12,15 juta ha) serta kenaikan produktivitas padi sebesar $1,3 \mathrm{kw} \mathrm{ha}^{-1}$ atau 2,76\% lebih tinggi dari produktivitas di tahun 2007.

Peningkatan produksi padi memiliki banyak kendala di antaranya adanya penyakit hawar daun bakteri (Tjubarjat et al., 1999; Suparyono et al., 2004; Kadir, 1999; Yashitola et al., 1997; Srinivasan \& Gnanamanickam, 2005), penyakit bercak coklat dan blas (Prihatiningsih \& Djatmiko, 2001). Salah satu penyakit utama padi sawah di Indonesia dan di Asia secara adalah hawar daun bakteri atau kresek yang disebabkan oleh Xanthomonas oryzae pv. oryzae (Xoo) (Kadir, 1999; Mundt et al., 1999; IRRI, 2003). Di Indonesia kehilangan yang diakibatkan oleh penyakit kresek mencapai 70-80\% (Kadir, 1999), di India mencapai 74 81\% ( Srinivasan \& Gnanamanickam, 2005), dan Jepang mencapai 20-50\% (IRRI, 2003), sehingga menyebabkan kerugian yang besar secara ekonomi (Yasin et al., 2005).

Berbagai upaya pengendalian penyakit hawar daun bakteri telah dilakukan, diantaranya dengan penggunaan antibiotik oxytetracycline, streptomycin, dan chloramphenicol (Khan et al., 2005); peramalan datangnya serangan patogen (Liu et al., 2006); sanitasi di pertanaman padi (IRRI, 2003) dan penggunaan kombinasi agensia antagonis Pantoea agglomerans, Pseudomonas fluorescens dan Bacillus subtilis AS (Babu \& Thind, 2005), serta penggunaan varietas tahan (Djatmiko \& Fatichin, 2009). Namun, cara pengendalian tersebut belum memberikan hasil yang memuaskan karena $X$. oryzae pv. oryzae mempunyai inang yang banyak yaitu Leersia sayanuka, L. oryzoides, $L$. japonica, Leptochola chinensis, L. filiformis, $L$. panicea, Cyperus rotundus, C. difformis, Oryza rifopogon dan $O$. australiensis (IRRI, 2003). Selain inang yang banyak, Xoo mempunyai tingkat keragaman patotipe tinggi yang disebabkan oleh lingkungan, varietas padi yang digunakan dan tingkat mutabilitas gen bakteri inggi (Keller et al., 2000).

Ketahanan inang adalah komponen penting program pengelolaan penyakit terpadu untuk penyakit hawar daun bakteri. Saat ini, 21 gen ketahanan telah diidentifikasi dan digunakan dalam program pemuliaan padi, namun ras baru Xoo segera nampak karena adanya tekanan seleksi yang disebabkan adanya kultivar tahan ras spesifik. Dalam kenyataannya, strain virulen Xoo terdeteksi pada kultivar tahan semenjak populasi inang mempengaruhi keragaman genetik dan struktur populasi patogen (Gupta et al., 2001).

Banyak sumber ketahanan terhadap penyakit hawar daun bakteri telah terindentifikasi di negara penanam padi di Asia, namun demikian pemuliaan padi untuk ketahanan terhadap Xoo masih dalam tahap awal. Informasi keberadaan populasi ras patogen di suatu daerah dapat digunakan untuk memilih dan membudidayakan plasma nutfah tahan. Penelitian pendahuluan menunjukkan bahwa di daerah pertanaman padi di Karesidenan Banyumas untuk wilayah Banjarnegara, Purbalingga, dan Purwokerto terserang berat oleh Xoo hingga mencapai $45 \%$ dan sampai saat ini patotipe dan genotipenya belum diketahui (Djatmiko \& Fatichin, 2007). Hasil penelitian awal Djatmiko \& Prakoso (2008) menunjukkan bahwa adanya perbedaan keragaman genetik Xoo yang berasal dari berbagai ketinggian tempat di Karesidenan Banyumas.

Berdasarkan pemikiran di atas, maka diperlukan penelitian tentang penentuan patotipe dan keragaman genetik Xoo pada tanaman padi di wilayah Karesidenan Banyumas.

Tujuan penelitian yaitu: 1) Mengkarakterisasi Xoo dari wilayah Banjarnegara, Purbalingga, Banyumas, Cilacap dan Kebumen; 2) Mengkaji besarnya kerusakan dan AUDPC (the area under disease progress curve) penyakit hawar daun bakteri di wilayah Banjarnegara, Purbalingga, Banyumas, Cilacap dan Kebumen; 3) Mendapatkan patotipe Xoo dengan menggunakan padi 
varietas uji; 4) Mendapatkan keragaman genetik Xoo yang ditemukan di wilayah Banjarnegara, Purbalingga, Banyumas, Cilacap dan Kebumen.

\section{METODE PENELITIAN}

Penelitian ini dilaksanakan selama 8 bulan mulai bulan April sampai November 2008. Penelitian di laboratorium dilaksanakan di Laboratorium Penyakit Tumbuhan dan Genetika, Fakultas Pertanian, Universitas Jenderal Soedirman, Purwokerto. Penelitian lapang dilaksanakan di wilayah Karesidenan Banyumas yang meliputi Banjarnegara, Purbalingga, Banyumas, Cilacap dan Kebumen.

Isolasi dan karakterisasi $X$. oryzae pv. oryzae dari wilayah Barlingmascakeb. Isolasi Xoo dengan menumbuhkan pada medium SPA atau sucrose peptone agar (Suparyono et al., 2004): daun bergejala hawar daun bakteri disterilkan permukaannya dengan alkohol $70 \%$, lalu dibilas dengan air steril tiga kali, dikeringanginkan dan dipotong dengan ukuran $5 \times 5 \mathrm{~mm}$, direndam dalam air steril selama 5 menit dalam tabung reaksi. Suspensi tersebut digoreskan pada medium SPA, inkubasi 48-72 jam, diperoleh koloni tunggal berwarna kuning, kemudian disimpan dalam medium SPA miring yang diberi parafin steril untuk disimpan pada suhu $4^{\circ} \mathrm{C}$ dan dalam air steril yang akan selalu digunakan untuk perbanyakan berikutnya. Dari hasil isolasi tersebut ditentukan 18 isolat Xoo yang digunakan untuk penelitian selanjutnya. Isolat tersebut dikarakterisasi secara fisika kimia untuk memastikan bahwa patogen hawar daun bakteri adalah Xoo yaitu ketahanan terhadap 0,001\% $\mathrm{Cu}\left(\mathrm{NO}_{3}\right)_{2}$, pertumbuhan pada $0,1 \%$ TZC, uji Gram, uji Katalase, hidrolisis pati dan pertumbuhan pada medium SPA.
Pengujian $X$. oryzae pv. oryzae dengan 5 varietas uji. Delapan belas isolat murni Xoo yang sudah dikarakterisasi, kemudian diinokulasikan pada padi varietas Kencana, PB5, Tetep, Kuntulan dan Jawa 14 untuk menentukan patotipe berdasarkan fenotipenya. Lima varietas padi tersebut adalah varietas uji umum digunakan untuk identifikasi dan mengklasifikasikan patotipe Xoo (Lee et al., 2003). Pelaksanaannya sebagai berikut: benih padi ditumbuhkan di larutan hara di nyiru bambu. Pada umur bibit 14 hari dipindahkan ke dalam pot dengan diameter $35 \mathrm{~cm}$ sebanyak 3 rumpun. Kerapatan inokulum Xoo yang diinokulasikan pada tanaman padi $10^{9} \mathrm{cfu} \mathrm{\textrm {ml } ^ { - 1 }}$ (Yashitola et al., 1997). Inokulasi isolat Xoo dilakukan dengan cara clip-method yaitu ujung daun padi dipotong kira-kira $2-3 \mathrm{~cm}$ dengan gunting yang sudah dicelupkan dalam suspensi Xoo, kemudian disungkup dengan plastik selama 24 jam dan diinkubasikan pada suhu $30^{\circ} \mathrm{C}$ (EPPO, 2007). Pengamatan dilakukan 2 minggu setelah inokulasi untuk mengetahui reaksi setiap varietas uji terhadap 18 isolat bakteri Xoo.

Variabel yang diamati. Variabel tersebut yaitu: sifat fisika dan kimia Xoo (Ketahanan terhadap 0,001\% $\mathrm{Cu}\left(\mathrm{NO}_{3}\right)_{2}$, pertumbuhan pada $0,1 \% \mathrm{TZC}$, uji Gram, uji Katalase, hidrolisis pati, pertumbuhan pada medium SPA), intensitas penyakit, AUDPC dan pola pita DNA.

Untuk menentukan patotipe Xoo maka perlu menghitung Intensitas Penyakit dengan rumus menurut Suparyono et al. (2004) sebagai berikut:

$$
\mathrm{IP}=\frac{\mathrm{a}}{\mathrm{b}} \times 100 \%
$$

\section{Keterangan:}

IP = intensitas penyakit (\%)

$\mathrm{a}=$ panjang gejala hawar daun bakteri $(\mathrm{mm})$

$\mathrm{b}=$ panjang daun secara keseluruhan $(\mathrm{mm})$

Tabel 1. Hubungan timbal balik varietas diferensial padi dan patogen Xoo berdasar Kadir (1999)

\begin{tabular}{lllllllllllll}
\hline \multirow{2}{*}{ Varietas } & \multicolumn{11}{c}{ Patotipe } \\
\cline { 2 - 13 } & I & II & III & IV & V & VI & VII & VIII & IX & X & XI & XII \\
\hline Kencana & R & R & R & R & R & R & R & R & R & R & R & T \\
PB5 & $\mathrm{T}$ & R & R & R & T & T & R & R & R & T & R & T \\
Tetep & T & T & R & R & T & R & R & R & T & R & T & T \\
Kuntulan & T & T & T & R & R & T & T & R & R & R & R & R \\
Jawa 14 & T & T & T & R & T & T & R & T & T & T & R & T \\
\hline
\end{tabular}

Keterangan: $\mathrm{T}=$ tahan; $\mathrm{R}=$ rentan. 
Reaksi ketahanan tanaman padi terhadap Xoo menggunakan pedoman Tabel 2 .

Penilaian intensitas penyakit hawar daun bakteri dan AUDPC di Wilayah Karesidenan Banyumas. Pengamatan intensitas penyakit penyakit hawar daun bakteri yang disebabkan oleh Xoo di Wilayah Karesidenan Banyumas menggunakan rumus sebagai berikut:

$$
\mathrm{IP}=\frac{\sum \mathrm{nx} \mathrm{v}}{\mathrm{N} \times \mathrm{Z}} \times 100 \%
$$

Keterangan:

IP = intensitas penyakit

$\mathrm{N}=$ jumlah tanaman dari tiap kategori serangan

$\mathrm{v}=$ kategori serangan

$\mathrm{N}=$ jumlah tanaman yang diamati

$\mathrm{Z}=$ nilai kategori tertinggi

Menurut Tjubarjat et al. (1999), kategori serangan Xoo yang digunakan yaitu:

0 = tidak ada serangan

1 = skala kerusakan $1-5 \%$

3 = skala kerusakan $6-12 \%$

5 = skala kerusakan $13-25 \%$

7 = skala kerusakan $26-50 \%$

9 = skala kerusakan $51-100 \%$

AUDPC relatif dihitung dengan menggunakan rumus yang dikemukakan oleh Ahmed et al. (1999) sebagai berikut:

$$
\text { AUDPC }=\frac{\sum_{i=1}^{n}\left[\frac{x_{i+1}+X_{i}}{2}\right] \times\left[t_{i+1}-t_{i}\right]}{N-1}
$$

Keterangan:

$\mathrm{X}_{\mathrm{i}}=$ keparahan penyakit pada waktu pengamatan

$\mathrm{t}=$ waktu sesudah infeksi tampak di lapangan (hari)

$\mathrm{n}=$ jumlah pengamatan

Pengujian keragaman genetik $X$. oryzae pv. oryzae. Uji keragamam berdasarkan pola pita DNA hasil RAPD dilakukan di Laboratorium Genetika, Program Studi Agroteknologi, Fakultas Pertanian, Universitas Jenderal Soedirman, Purwokerto. Pengujian ini merupakan modifikasi Prakoso (2003) dengan tahapan sebagai berikut:
Ekstraksi DNA bakteri Xoo dengan metode Wizard Genomic DNA Purification System Kit dari Promega. Kultur bakteri Xoo ditumbuhkan dalam 10 $\mathrm{ml}$ medium pepton cair 5\% dan digojog dengan shaker selama satu malam. Kultur bakteri Xoo sebanyak $1 \mathrm{ml}$ dipindahkan ke dalam tabung 1,5 ml, kemudian disentrifus $14.000 \mathrm{rpm}$ dengan sentrifus IEC Micro-MB selama 1 menit. Supernatan dibuang. Proses yang sama diulangi satu kali. Pelet yang terbentuk ditambah $600 \mu \mathrm{l}$ Cell Lysis Solution hangat dan dihomogenkan. Suspensi sel diinkubasi pada suhu $65^{\circ} \mathrm{C}$ selama 30 menit, sambil digojog $150 \mathrm{rpm}$ pada waterbath jenis BS-31. Setelah itu tabung dibiarkan pada suhu ruang selama 5 menit. RNase $3 \mu l$ ditambahkan pada tabung, dihomogenkan, kemudian diinkubasi pada suhu $37^{\circ} \mathrm{C}$ selama 1 jam pada waterbath BS-31 sambil digojog 150 rpm. Ditambahkan $30 \mu 1$ Protein Presipitation Solution, digojog dengan vortex selama 5 menit, kemudian disentrifus $14.000 \mathrm{rpm}$ dengan sentrifus IEC Micro-MB selama 2 menit. Supernatan sebanyak $600 \mu l$ dipindahkan ke tabung 1,5 ml baru. Ditambahkan $300 \mu$ l isopropanol, dibolak-balik sebanyak 10 kali, kemudian disentrifus $14.000 \mathrm{rpm}$ dengan sentrifus IEC Micro-MB selama 2 menit. Supernatan dibuang, pelet ditambah etanol $70 \%$ sebanyak $500 \mu$ l. Tabung disentil hingga pelet lepas dari dinding tabung, kemudian dibolak-balik sepuluh kali, disentrifus $14.000 \mathrm{rpm}$ dengan sentrifus IEC Micro-MB selama 1 menit, kemudian supernatan dibuang. Pelet dikeringkan dalam LAF selama 30 menit, dengan posisi tutup tabung terbuka agar etanol yang tertinggal dalam tabung menguap. Pelet dilarutkan dalam air steril 100 $\mu l$ dan digunakan sebagai DNA stok. Absorbansi larutan DNA diukur dengan spektrofotometer pada panjang gelombang $260 \mathrm{~nm}$ dan $280 \mathrm{~nm}$ untuk menentukan konsentrasinya. Larutan DNA siap digunakan

\section{Pengukuran kualitas dan kuantitas DNA hasil} ekstraksi. DNA hasil ekstraksi divortek selama 1 menit. Spektrofotometer disiapkan hingga stabil, kemudian diatur pada panjang gelombang $260 \mathrm{~nm}$. Dua buah kuvet disiapkan, kuvet pertama diisi dengan air steril sebanyak $120 \mu \mathrm{l}$ dan dijadikan sebagai blangko, kemudian kuvet kedua diisi dengan $20 \mu \mathrm{l}$ DNA yang telah ditambah air sebanyak $100 \mu 1$. Kuvet dimasukkan ke dalam spektrofotometer untuk mengetahui nilai absorbansinya. Spektrofotometer diatur pada $280 \mathrm{~nm}$ dan dilakukan hal yang sama untuk mengetahui nilai serapannya. 
Analisis RAPD pada 18 isolat Xoo. Analisis RAPD dilakukan dengan mesin PCR untuk mengamplifikasi DNA, dengan menggunakan bahan larutan campuran yang berisi Easy Do PCR pre Mix sebanyak $15 \mu$ l, DNA working dengan konsentrasi $20 \mathrm{ng} \mu \mathrm{l}^{-1}$ sebanyak $5 \mu \mathrm{l}$,

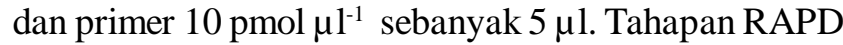
dilakukan dengan siklus dan pengaturan suhu seperti pada Tabel 3.

Elektroforesis. Elektroforesis DNA dilakukan pada $1,5 \%$ gel agarose yang diberi DNA marker pada salah satu sumurnya. DNA hasil RAPD sebanyak 12,5 $\mu 1$ dan DNA marker sebanyak $5 \mu$ l dimasukkan ke dalam sumur gel agarose, satu sumur mewakili satu DNA. Elektroforesis dijalankan pada tegangan $80 \mathrm{~V}$ selama 90 menit. Pita DNA hasil elektroforesis akan terlihat dengan meletakkan gel di atas UV transilluminator dan didokumentasikan dengan kamera digital.
Analisis Data. Data hasil bakteri isolasi dari daun padi bergejala hawar daun bakteri, karakterisasi isolat bakteri berdasar sifat kimia, penilaian penyakit, AUDPC, uji Xoo pada padi 5 varietas uji (standar), maupun keragaman genetik dianalisis secara deskriptif.

\section{HASIL DAN PEMBAHASAN}

Isolasi dan Karakterisasi Patogen Hawar Daun bakteri. Isolat yang digunakan berasal dari Banjarnegara, Purbalingga, Banyumas, Cilacap, dan Kebumen. Seluruh sampel daun bergejala hawar daun bakteri ditumbuhkan pada medium SPA (Sucrose Peptone Agar). Patogen hawar daun bakteri diuji lanjut dengan menguji sifat biokimia ditunjukkan pada Tabel 4.

Pada Tabel 4 menunjukkan bahwa patogen hawar daun bakteri adalah Xoo. Hal tersebut sesuai dengan

Tabe1 2. Reaksi tanaman padi berdasarkan nilai kerusakan daun

\begin{tabular}{cc}
\hline Reaksi Tanaman & Nilai Kerusak an Daun \\
\hline Tahan & $<10 \mathrm{~mm}$ \\
Rentan & $>10 \mathrm{~mm}$ \\
\hline
\end{tabular}

Tabel 3. Siklus dan pengaturan suhu PCR untuk RAPD 18 isolat Xoo

\begin{tabular}{|c|c|c|c|}
\hline Fase & Temperatur & Durasi Waktu & Siklus \\
\hline Denaturasi awal & $94^{\circ} \mathrm{C}$ & 5 menit & 1 kali \\
\hline Denaturasi & $94^{\circ} \mathrm{C}$ & 1 menit & \\
\hline Penempelan primer & $36^{\circ} \mathrm{C}$ & 1,5 menit & 40 kali \\
\hline Sintesis DNA & $72^{\circ} \mathrm{C}$ & 3 menit & \\
\hline Sintesis DNA akhir & $72^{\circ} \mathrm{C}$ & 10 menit & 1 kali \\
\hline Hold & $4^{\circ} \mathrm{C}$ & Tak terhingga & \\
\hline
\end{tabular}

Tabel 4. Karakterisasi bakteri sebagai patogen hawar daun bakteri

\begin{tabular}{lc}
\hline \multicolumn{1}{c}{ Pengujian Biokimia } & Hasil Pengujian \\
\hline Pertumbuhan pada medium SPA & Warna koloni kuning \\
Reaksi gram & Negatif \\
Katalase & Positif \\
Oksidase & Negatif \\
Pertumbuhan pada $0,1 \%$ TZC & Negatif \\
Hidrolisis pati & Positif \\
Ketahanan terhadap $0,001 \% \mathrm{Cu}\left(\mathrm{NO}_{3}\right)_{2}$ & Positif \\
\hline
\end{tabular}


penelitian Djatmiko \& Fatichin (2009), berdasarkan pengujian biokimia patogen hawar daun bakteri yaitu pertumbuhan pada medium SPA, reaksi gram, uji katalase, oksidase, O/F, pertumbuhan pada $0,1 \% \mathrm{TZC}$, hidrolisis pati, dan ketahanan terhadap $0,001 \% \mathrm{Cu}\left(\mathrm{NO}_{3}\right)_{2}$ menunjukkan bahwa patogen hawar daun bakteri yaitu Xoo. Menurut Schaad et al. (2001), bakteri kelompok Xanthomonas mempunyai sifat oksidase negatif. Genus bakteri kelompok Xanthomonas yang ditumbuhkan pada medium SPA menunjukkan sifat gram negatif (Moffett \& Croft, 1983), mempunyai flagelum polar tunggal, dan bersifat patogen pada tanaman (Schaad et al., 2001).

Katalase adalah enzim yang mempunyai kemampuan mendekomposisi $\mathrm{H}_{2} \mathrm{O}_{2}$ menjadi $\mathrm{H}_{2} \mathrm{O}$ dan $\mathrm{O}_{2}$ (Sands, 1990). Lebih lanjut dikatakan, sebagian besar bakteri mempunyai sifat katalase positif. Sebagian besar bakteri kelompok Xanthomonas mempunyai sifat katalase positif dan tidak membentuk spora (Liu et al., 2006), serta menghasilkan polisakarida luarsel sebagai sumber "xanthan gum" pada medium yang mengandung glukosa (Schaad et al., 2001). Polisakarida luarsel sangat penting dalam pembentukan eksudat bakteri dari daun terinfeksi, melindungi dari kekeringan, dan membantu penyebaran lewat hujan dan angin (Liu et al., 2006).

Pertumbuhan patogen hawar daun bakteri pada medium SPA yang mengandung $0,1 \%$ TZC menunjukkan reaksi negatif karena koloni yang tumbuh berwarna oranye bukan merah muda. Warna koloni merah muda menunjukkan bahwa bakteri tersebut bukan Xanthomanas oryzae. Menurut Schaad et al. (2001), bahwa pertumbuhan Xanthomanas oryzae menunjukan reaksi negatif terhadap $0,1 \%$ TZC.

Bakteri hawar daun bakteri pada medium yang mengandung pati, setelah 2 hari inkubasi digenangi larutan lugol (iodin + potassium iodide) menunjukkan adanya zona terang di sekitar koloni, sehingga mempunyai kemampuan menghidrolisis pati. Patovar Xanthomonas oryzae mempunyai kemampuan menghidrolisis pati (Moffett \& Croft, 1983; Rudolph et al., 1990) atau aktivitas amilase (Fahy \& Hayward, 1983).

Salah satu yang membedakan antara penyakit hawar daun bakteri (bacterial leaf blight) atau penyakit kresek yang disebabkan oleh Xoo dan bacterial leaf streak yang disebabkan oleh Xanthomonas oryzae pv. oryzicola adalah ketahanannya terhadap 0,001\% $\mathrm{Cu}\left(\mathrm{NO}_{3}\right)_{2}$ (Liu et al., 2006). Patogen hawar daun bakteri yang ditumbuhkan pada medium SPA mengandung $0,001 \% \quad \mathrm{Cu}\left(\mathrm{NO}_{3}\right)_{2}$ menunjukkan pertumbuhan yang baik dengan koloni berwarna kuning dan berbentuk bulat. Menurut Liu et al. (2006), bahwa Xoo mempunyai respon positif terhadap $0,001 \%$ $\mathrm{Cu}\left(\mathrm{NO}_{3}\right)_{2}$ dan Xanthomonas oryzae pv. oryzicola berespons negatif terhadap $0,001 \% \mathrm{Cu}\left(\mathrm{NO}_{3}\right)_{2}$.

Hasil tersebut sesuai dengan peneliti lain yang ditunjukkan pada Tabel 5. Berdasarkan Tabel tersebut menunjukkan bahwa bakteri yang diuji termasuk Xoo.

Penentuan Patotipe $X$. oryzae pv. oryzae dari Barlingmascakeb. Penentuan patotipe Xoo pada lima varietas standar dari berbagai barlingmascakeb ditunjukkan Tabel 6.

Hasil inokulasi Xoo pada 5 varietas padi (Kencana, PB5, Tetep, Kuntulan, dan Jawa 14) menunjukkan intensitas penyakit dan reaksi tanaman beragam. Hal ini menunjukkan adanya keragaman isolat tersebut dalam menyebabkan reaksi ketahanan pada 5 varietas padi. Berdasarkan Tabel 6 dan penentuan patotipe menurut Kadir (1999), isolat Bj1 (isolat asal Banjarnegara) digolongkan patotipe $\mathrm{X}$ dan isolat $\mathrm{C} 4$ (isolat asal Cilacap), serta P2 (isolat asal Purbalingga) digolongkan patotipe II, sedangkan C5 (isolat asal Cilacap) digolongkan patotipe I.

Daerah Kabupaten Banyumas dan Kebumen tidak terdeteksi berdasarkan pengolongan patotipe yang dikembangkan oleh Kadir (1999), diduga Xoo di Kabupaten Banyumas dan Kebumen mempunyai patotipe baru.

Penyebaran Xoo patotipe X, II dan I, dan II masing-masing ada di Kabupaten Banjarnegara, Cilacap, dan Purbalingga. Hal berkaitan di 3 kabupaten penanam varietas Ciherang yang disukai oleh petani di daerah tersebut. Varietas Ciherang adalah varietas yang rentan terhadap penyakit hawar daun bakteri. Selain itu, seiring dengan meluasnya penanaman padi varietas Ciherang yang rentan terhadap penyakit hawar daun bakteri menyebabkan kelompok patotipe baru menjadi berkembang di suatu wilayah. Menurut Reddy et al. (1979), bahwa penyakit hawar daun bakteri berkembang pesat pada varietas padi yang rentan. Beragamnya patotipe di lapangan karena adanya perbedaan sifat fisiologis tanaman maupun faktor lingkungan (suhu dan kelembapan). Suhu dan kelembaban di daerah Banjarnegara, Cilacap, dan Purbalingga yaitu masingmasing $24-27^{\circ} \mathrm{C}$ dan $60-75 \%$, sedangkan suhu optimum yang menguntungkan perkembangan penyakit hawar daun bakteri adalah $26-30^{\circ} \mathrm{C}$. Menurut Hwang et al. (1987 dalam Sudir, 2009), bahwa faktor yang berpengaruh terhadap interaksi stadium tumbuh tanaman dengan variasi patotipe patogen adalah fenomena sifat 
Tabel 5. Sifat biokimia dan fisiologi bakteri uji

\begin{tabular}{|c|c|c|c|c|c|c|}
\hline \multirow{2}{*}{ Pengujian } & \multirow{2}{*}{$\begin{array}{c}\text { Bakteri } \\
\text { yang diuji }\end{array}$} & \multicolumn{5}{|c|}{ X. oryzae pv. oryzae } \\
\hline & & $\begin{array}{l}\text { Goto } \\
(1992)\end{array}$ & $\begin{array}{c}\text { Lelliot \& } \\
\text { Stead (1987) }\end{array}$ & $\begin{array}{c}\text { Moffett \& } \\
\text { Croft (1983) }\end{array}$ & $\begin{array}{l}\text { Schaad et al. } \\
\quad \text { (2001) }\end{array}$ & $\begin{array}{l}\text { Liu et al. } \\
\text { (2006) }\end{array}$ \\
\hline Uji reaksi gram & Negatif & Negatif & Negatif & Negatif & Negatif & Negatif \\
\hline Uji katalase & Positif & $\mathrm{T}$ & Positif & Positif & Positif & Positif \\
\hline Uji oksidase & Negatif & $\mathrm{T}$ & Negatif & Negatif & Negatif & $\mathrm{T}$ \\
\hline $\mathrm{Uji} \mathrm{O} / \mathrm{F}$ & $\mathrm{T}$ & Oksidatif & Oksidatif & $\mathrm{T}$ & Oksidatif & Oksidatif \\
\hline $\begin{array}{l}\text { Pertumbuhan pada } \\
0,1 \% \text { TZC }\end{array}$ & Negatif & Negatif & Negatif & $\mathrm{T}$ & $\mathrm{T}$ & $\mathrm{T}$ \\
\hline $\begin{array}{l}\text { Pertumbuhan pada } \\
\text { medium YDC }\end{array}$ & Positif & $\mathrm{T}$ & $\mathrm{T}$ & $\mathrm{T}$ & $\begin{array}{l}\text { Positif } \\
\text { (kuning) }\end{array}$ & $\mathrm{T}$ \\
\hline $\begin{array}{l}\text { Ketahanan terhadap } \\
0,001 \% \mathrm{Cu}\left(\mathrm{NO}_{3}\right)_{2}\end{array}$ & Positif & $\mathrm{T}$ & $\mathrm{T}$ & $\mathrm{T}$ & $\mathrm{T}$ & Positif \\
\hline $\begin{array}{l}\text { Pertumbuhan pada } \\
\text { medium SPA }\end{array}$ & $\begin{array}{l}\text { Kuning, } \\
\text { bulat, } \\
\text { halus, } \\
\text { cembung, } \\
\text { berlendir }\end{array}$ & $\begin{array}{l}\text { Kuning, } \\
\text { bulat, } \\
\text { halus, } \\
\text { cembung, } \\
\text { berlendir }\end{array}$ & $\begin{array}{l}\text { Kuning, } \\
\text { bulat, } \\
\text { halus, } \\
\text { cembung, } \\
\text { berlendir }\end{array}$ & $\begin{array}{l}\text { Kuning, } \\
\text { bulat, } \\
\text { halus, } \\
\text { cembung, } \\
\text { berlendir }\end{array}$ & $\mathrm{T}$ & $\mathrm{T}$ \\
\hline $\begin{array}{l}\text { Pertumbuhan pada } \\
\text { suhu } 35^{\circ} \mathrm{C}\end{array}$ & $\mathrm{T}$ & $\mathrm{T}$ & $\mathrm{T}$ & Positif & Positif & $\mathrm{T}$ \\
\hline Hidrolisis pati & Positif & $\mathrm{T}$ & $\mathrm{T}$ & $\mathrm{T}$ & $\mathrm{T}$ & $\mathrm{T}$ \\
\hline
\end{tabular}

Keterangan: $\mathrm{T}=$ tidak diamati.

Tabel 6. Hasil inokulasi Xoo pada lima varietas uji padi (Kencana, PB5, Tetep, Kuntulan, dan Jawa 14)

\begin{tabular}{|c|c|c|c|c|c|c|c|c|c|c|c|}
\hline \multirow{2}{*}{ Isolat } & \multicolumn{2}{|c|}{ Kencana } & \multicolumn{2}{|c|}{ PB5 } & \multicolumn{2}{|c|}{ Tetep } & \multicolumn{2}{|c|}{ Kuntulan } & \multicolumn{2}{|c|}{ Jawa 14} & \multirow{2}{*}{ Patotipe } \\
\hline & $\operatorname{IP}(\%)$ & Reaksi & IP (\%) & Reaksi & IP (\%) & Reaksi & IP (\%) & Reaksi & $\operatorname{IP}(\%)$ & Reaksi & \\
\hline $\mathrm{Bj} 1$ & 26,9 & $\mathrm{R}$ & 8,7 & $\mathrm{~T}$ & 21,1 & $\mathrm{R}$ & 26,3 & $\mathrm{R}$ & 4,6 & $\mathrm{~T}$ & $\mathrm{X}$ \\
\hline $\mathrm{Bj} 3$ & 3,4 & $\mathrm{~T}$ & 20,33 & $\mathrm{R}$ & 29,1 & $\mathrm{R}$ & 3,9 & $\mathrm{~T}$ & 3,8 & $\mathrm{~T}$ & Negatif \\
\hline $\mathrm{Bj} 4$ & 5,04 & $\mathrm{~T}$ & 39,22 & $\mathrm{R}$ & 23,8 & $\mathrm{R}$ & 1,1 & $\mathrm{~T}$ & 100 & $\mathrm{R}$ & Negatif \\
\hline B3 & 8,5 & $\mathrm{~T}$ & 14,1 & $\mathrm{R}$ & 1,6 & $\mathrm{~T}$ & 1,4 & $\mathrm{~T}$ & 18,25 & $\mathrm{R}$ & Negatif \\
\hline B4 & 1,7 & $\mathrm{~T}$ & 13,7 & $\mathrm{R}$ & 26,4 & $\mathrm{R}$ & 1,03 & $\mathrm{~T}$ & 100 & $\mathrm{R}$ & Negatif \\
\hline $\mathrm{C} 4$ & 14,3 & $\mathrm{R}$ & 19,8 & $\mathrm{R}$ & 2,08 & $\mathrm{~T}$ & 6,8 & $\mathrm{~T}$ & 1,8 & $\mathrm{~T}$ & II \\
\hline $\mathrm{C} 5$ & 48,6 & $\mathrm{R}$ & 0 & $\mathrm{~T}$ & 1,96 & $\mathrm{~T}$ & 0,83 & $\mathrm{~T}$ & 3,3 & $\mathrm{~T}$ & I \\
\hline K1 & 23,7 & $\mathrm{R}$ & 0 & $\mathrm{~T}$ & 21,5 & $\mathrm{R}$ & 27,7 & $\mathrm{R}$ & 55,5 & $\mathrm{R}$ & Negatif \\
\hline $\mathrm{K} 2$ & 3,8 & $\mathrm{~T}$ & 6,5 & $\mathrm{~T}$ & 14,3 & $\mathrm{R}$ & 26,7 & $\mathrm{R}$ & 4,8 & $\mathrm{~T}$ & Negatif \\
\hline $\mathrm{K} 3$ & 11,7 & $\mathrm{R}$ & 0,9 & $\mathrm{~T}$ & 2,7 & $\mathrm{~T}$ & 17,8 & $\mathrm{R}$ & 100 & $\mathrm{R}$ & Negatif \\
\hline K4 & 11,02 & $\mathrm{R}$ & 0 & $\mathrm{~T}$ & 16,1 & $\mathrm{R}$ & 27,8 & $\mathrm{R}$ & 46,7 & $\mathrm{R}$ & Negatif \\
\hline K5 & 3,3 & $\mathrm{~T}$ & 3,26 & $\mathrm{~T}$ & 31,9 & $\mathrm{R}$ & 12,3 & $\mathrm{R}$ & 1,6 & $\mathrm{~T}$ & Negatif \\
\hline K6 & 2,6 & $\mathrm{~T}$ & 0,23 & $\mathrm{~T}$ & 75,7 & $\mathrm{R}$ & 36,4 & $\mathrm{R}$ & 37,8 & $\mathrm{R}$ & Negatif \\
\hline K7 & 2,7 & $\mathrm{~T}$ & 14,3 & $\mathrm{R}$ & 3,17 & $\mathrm{~T}$ & 2,8 & $\mathrm{~T}$ & 24,6 & $\mathrm{R}$ & Negatif \\
\hline P1 & 74,7 & $\mathrm{R}$ & 1,36 & $\mathrm{~T}$ & 1,4 & $\mathrm{~T}$ & 56,4 & $\mathrm{R}$ & 75,8 & $\mathrm{R}$ & Negatif \\
\hline P2 & 19,43 & $\mathrm{R}$ & 17,7 & $\mathrm{R}$ & 1,44 & $\mathrm{~T}$ & 2,9 & $\mathrm{~T}$ & 4,1 & $\mathrm{~T}$ & II \\
\hline
\end{tabular}

Keterangan: Bj1, Bj3, Bj4: isolat Xoo asal Banjarnegara; B3 dan B4: isolat Xoo asal Banyumas; C4 dan C5: isolat Xoo asal Cilacap; K1, K2, K3, K4, K5, K6, dan K7: isolat Xoo asal Kebumen; P1 dan P2: isolat $\mathrm{Xoo}$ asal Purbalingga. 
tahan yang muncul pada saat tanaman mencapai umur tertentu, mutasi gen patogen, dan sifat heterogen alamiah yang ada pada populasi patogen.

Pengamatan Intensitas Penyakit dan AUDPC. Pengukuran intensitas penyakit hawar daun bakteri dan AUDPC dilakukan di 5 kabupaten selama 8 kali pengamatan (Tabel 7).

Tabel 7 menunjukkan bahwa intensitas penyakit dan AUDPC (per hari) tertinggi masing-masing adalah 44,62\% dan 0,2996\% di Kabupaten Kebumen dan terendah di Kabupaten Banjarnegara masing-masing adalah $1,60 \%$ dan 0,0092 . Berdasarkan kenyataan tersebut, penyakit hawar daun bakteri berpotensi menimbulkan epidemi di Kabupaten Kebumen. Selain itu, penyakit hawar daun bakteri di Kabupaten Cilacap dan Banyumas juga berpotensi menimbulkan epidemi karena menunjukkan peningkatan perkembangan penyakit secara nyata (Gambar 1).

Besarnya intensitas penyakit di Kabupaten Kebumen dikarenakan lingkungan areal pertanaman padi sesuai dengan perkembangan penyakit hawar daun bakteri, diantaranya ketinggian tempat ( $8 \mathrm{~m} \mathrm{dpl})$, suhu sekitar $24-27^{\circ} \mathrm{C}$. Selain itu, faktor lain juga mendukung yaitu varietas Ciherang padi merupakan varietas yang rentan, belum pernah dilakukan pengendalian terhadap penyakit hawar daun bakteri. Pupuk kandang berpengaruh nyata terhadap keparahan penyakit hawar daun bakteri (Sudir \& Abdulrachman, 2009). Menurut Reddy et al. (1979), faktor yang mempengaruhi perkembangan penyakit hawar daun bakteri yaitu aplikasi pupuk Nitrogen yang tinggi. Pemupukan

Tabel 7. Intensitas penyakit hawar daun bakteri dan AUDPC di Wilayah Karesidenan Banyumas

\begin{tabular}{|c|c|c|c|c|c|c|c|c|c|}
\hline \multirow{2}{*}{ Kabupaten } & \multicolumn{8}{|c|}{ Intensitas Penyakit (\%) pada minggu ke- } & \multirow{2}{*}{$\begin{array}{c}\text { AUDPC } \\
\text { relatif }\end{array}$} \\
\hline & 1 & 2 & 3 & 4 & 5 & 6 & 7 & 8 & \\
\hline Banjarnegara & 0,50 & 0,70 & 0,80 & 1,00 & 1,20 & 1,50 & 1,50 & 1,60 & 0,0092 \\
\hline Banyumas & 1,85 & 3,7 & 7,78 & 8,15 & 31,11 & 31,85 & 33,33 & 37,04 & 0,1606 \\
\hline Cilacap & 0,00 & 0,00 & 9,26 & 9,26 & 9,26 & 9,63 & 13,33 & 24,44 & 0,0707 \\
\hline Kebumen & 25,76 & 32,18 & 32,64 & 34,18 & 36,16 & 38,84 & 43,30 & 44,62 & 0,2996 \\
\hline Purbalingga & 0 & 0 & 0 & 3,70 & 3,70 & 3,70 & 4,40 & 4,40 & 0,0210 \\
\hline
\end{tabular}

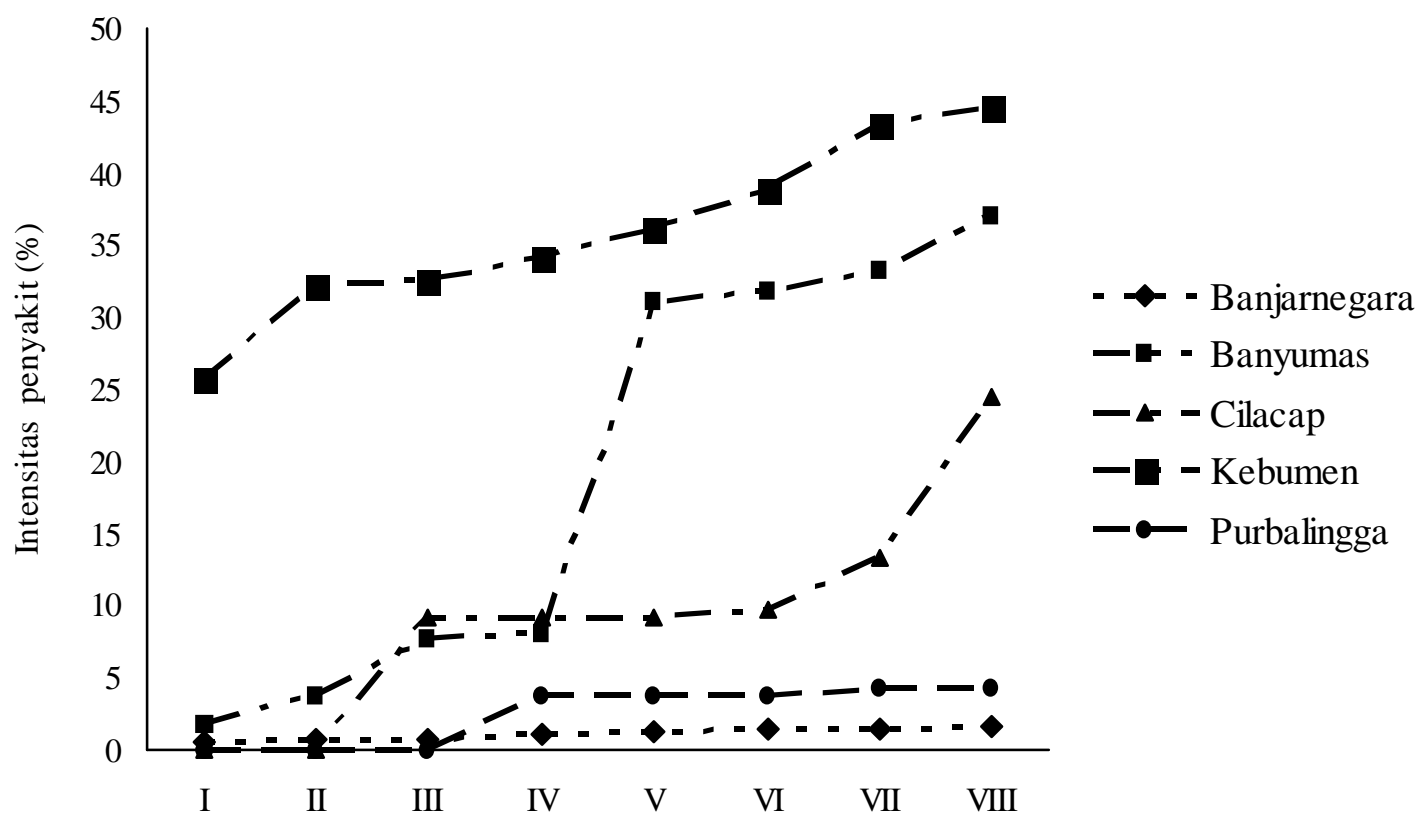

Gambar 1. Perkembangan penyakit hawar daun bakteri di Kabupaten Banjarnegara, Banyumas, Cilacap, Kebumen, dan Purbalingga 


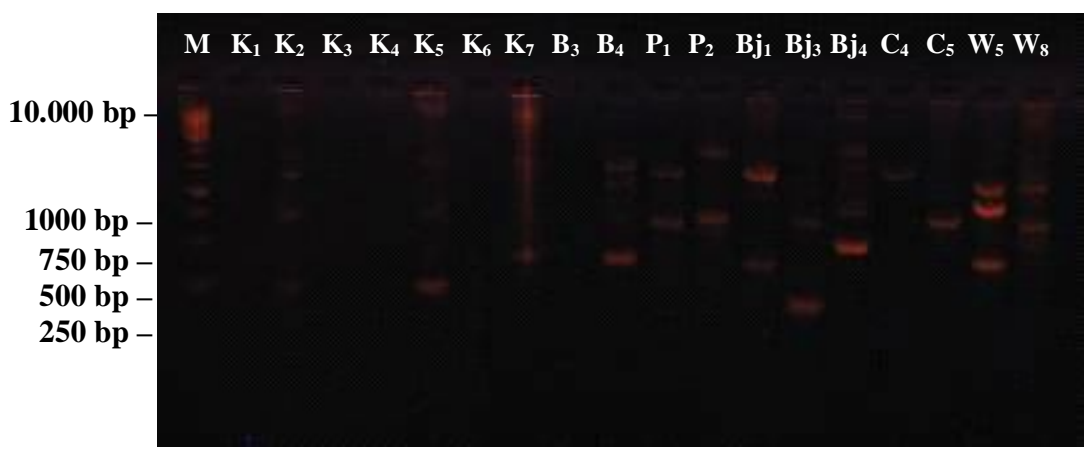

Gambar 2. Pola pita hasil RAPD menggunakan primer OPA 10

Keterangan: $\mathrm{M}=1 \mathrm{~Kb}$ DNA ladder dari Fermentas; $\mathrm{K}_{1}-\mathrm{W}_{8}=$ hasil RAPD isolat Xoo.

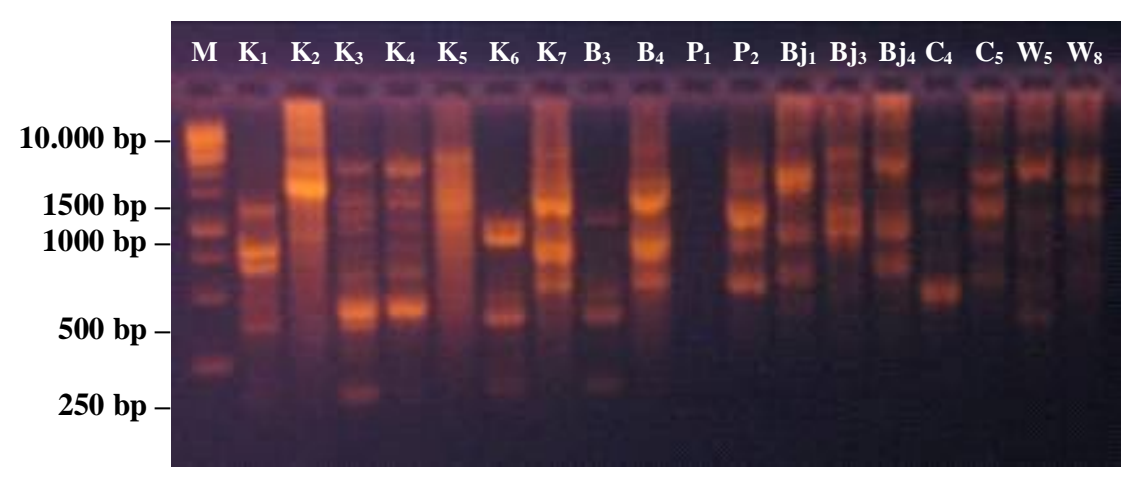

Gambar 3. Pola pita hasil RAPD menggunakan primer OPA 18

Keterangan: $\mathrm{M}=1 \mathrm{~Kb}$ DNA ladder dari Fermentas; $\mathrm{K}_{1}-\mathrm{W}_{8}=$ hasil RAPD isolat Xoo.

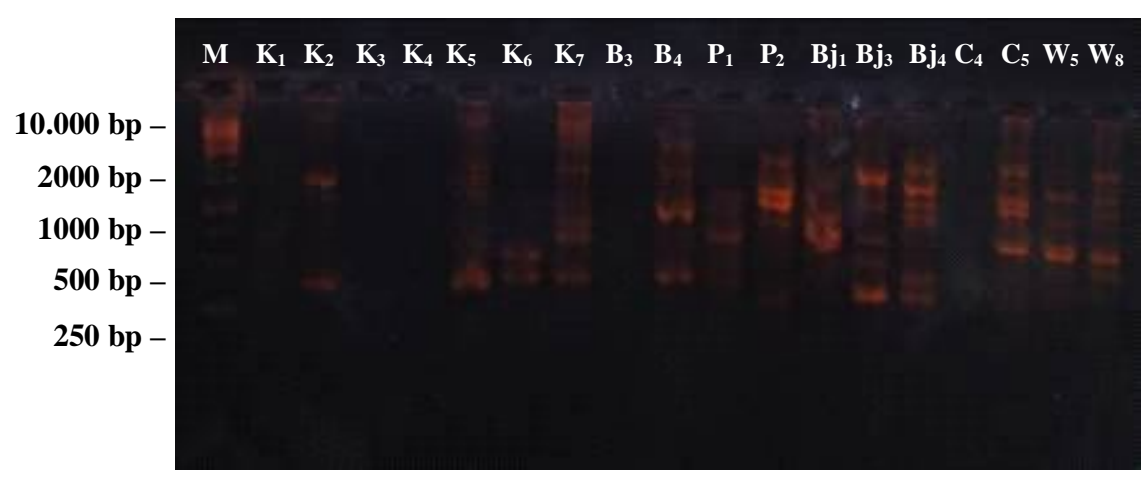

Gambar 4. Pola pita hasil RAPD menggunakan primer OPA 244.

Keterangan: $\mathrm{M}=1 \mathrm{~Kb}$ DNA ladder dari Fermentas; $\mathrm{K}_{1}-\mathrm{W}_{8}=$ hasil RAPD isolat Xoo. 


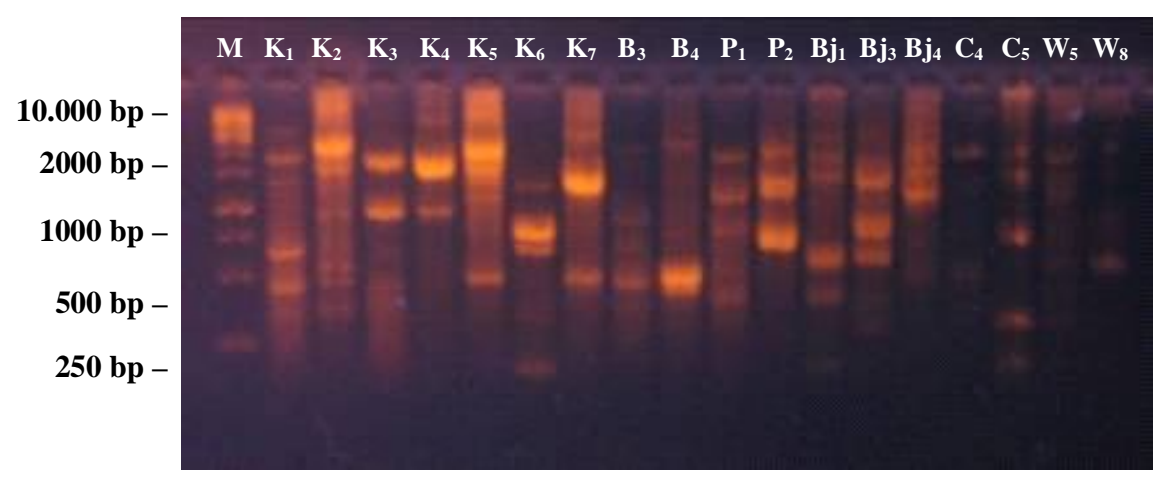

Gambar 5. Pola pita hasil RAPD menggunakan primer UBC 100

Keterangan: $\mathrm{M}=1 \mathrm{~Kb}$ DNA ladder dari Fermentas; $\mathrm{K}_{1}-\mathrm{W}_{8}=$ hasil RAPD isolat Xoo.

Nitrogen yang tinggi juga mempengaruhi perbanyakan patogen dan perkembangan bercak.

\section{Keragaman Patotipe dan Genotipe Xoo dari} Barlingmascakeb. Keragaman genotipe 18 isolat Xoo yang diamati dengan pola RAPD ditunjukkan pada Gambar 2, 3, 4, dan 5.

Gambar 2-5 menunjukkan pola pita 18 isolat Xoo dengan menggunakan primer OPA 10, OPA 18, OPA 244, dan UBC 100, dengan marker 1 kb dari Fermentas. Berdasarkan gambar dapat terlihat adanya perbedaan jumlah dan ukuran pita DNA dari 18 isolat Xoo hasil RAPD, kecuali pada primer OPA 18 isolat $\mathrm{K}_{7}$ dan $\mathrm{B}_{4}$ menunjukkan adanya persamaan pola pita DNA. Tetapi dengan menggunakan primer OPA 10, OPA 244, dan UBC 100 isolat $\mathrm{K}_{7}$ dan $\mathrm{B}_{4}$ menunjukkan pola pita yang berbeda.

Ukuran basa tertinggi pada primer OPA 10, OPA 18, dan UBC 100 yaitu di atas $10.000 \mathrm{bp}$, dan ukuran basa terendah yaitu di bawah $250 \mathrm{bp}$. Sedangkan pada primer OPA 244, isolat dengan ukuran basa tertinggi adalah $10.000 \mathrm{bp}$ dan yang terendah berukuran antara 250-500 bp. Variasi ukuran dan jumlah pita DNA pada hasil elektroforesis memungkinkan adanya perbedaan genetik 18 isolat Xoo asal 6 wilayah Kabupaten yaitu Banjarnegara, Banyumas, Cilacap, Kebumen, dan Purbalingga.

\section{SIMPULAN}

Penyebab penyakit hawar daun bakteri pada tanaman padi di Wilayah Karesidenan Banyumas adalah Xoo dengan ciri warna koloni kuning pada medium SPA, reaksi gram negatif, katalase positif, oksidase negatif, pertumbuhan pada $0,1 \%$ TZC negatif, hidrolisis pati negatif, dan ketahanan terhadap $0,001 \% \mathrm{Cu}\left(\mathrm{NO}_{3}\right)_{2}$ positif. Kerusakan serangan Xoo dan AUDPC terbesar ada di Kabupaten Kebumen yaitu masing-masing $44,62 \%$ dan 0,2996\%. Patotipe Xoo yang ditemukan di Kabupaten Banjarnegara yaitu patotipe X, Kabupaten Cilacap yaitu patotipe I dan II, dan Kabupaten Purbalingga yaitu patotipe II, berbeda dengan yang umum di Jawa Barat yaitu patotipe IV dan VIII. Delapan belas isolat Xoo yang berasal dari Wilayah Karesidenan Banyumas (Banjarnegara, Purbalingga, Banyumas, Cilacap, dan Kebumen) berdasarkan pola pita hasil RAPD DNA berbeda satu dengan yang lain

\section{SANWACANA}

Terima kasih kepada Direktorat Pembinaan Penelitian dan Pengabdian kepada Masyarakat Direktorat Jenderal Pendidikan Tinggi Kementerian Pendidikan Nasional atas dana Hibah Penelitian Strategi Nasional dan Fundamental tahun 2009 yang diberikan.

\section{DAFAR PUSTAKA}

Abdullah B. 2002. Inovasi teknologi padi tipe baru, pengelolaan tanaman dan sumber daya terpadu dan integrasi padi dan ternak. Semninar Temu Lapang Balitpa, Subang 26 September 2002.

Ahmed HU, Finckh MR, Alfonso RF \& Mundt CC. 1999. Epidmiological efect of gene deployment strategies on bacterial blight of rice. Phytopathology 87: 66-70.

Babu AG \& Thind BS. 2005. Potential use of combinations of Pantoea agglomerans, 
Pseudomonas fluorescens, and Bacillus subtilis AS biocontrol agents for the control of bacterial blight of rice. http://www.agridept.gov.lk/ other_sub_pages.php?id=8. Diakses tanggal 10 Oktober 2009.

BPS. 2006. Production of paddy maize and soybeans. (On line) http://www.bps.go.id/releases/ Production of Paddy Maize and Soybeans/Bahasa Indonesia/index.html. Diakses tanggal 29 Desember 2006.

BPS. 2008. Produksi padi, jagung, dan kedelai. (Angka perkiraan sementara tahun 2007 dan angka ramalan I Tahun 2008). (On-line). http:// www.bps.go.id/release/files/aram-03mar08.pdf. Diakses tanggal 14 Oktober 2008.

Djatmiko HA \& Fatichin. 2007. Ketahanan 20 varietas padi terhadap penyakit hawar daun bakteri. Laporan Penelitian. Fakultas Pertanian, Unsoed, Purwokerto.

Djatmiko HA \& Fatichin. 2009. Ketahanan dua puluh satu varietas padi terhadap penyakit hawar daun bakteri. J. Hama dan Penyakit Tumbuhan Tropika 9: 168-173.

Djatmiko HA \& Prakoso. 2008. Keragaman patotipe dan genotpe Xanthomonas oryzae pv. oryzae pada tanaman padi dari berbagai ketinggian tampat. Laporan Penelitian. Fakultas Pertanian. Unsoed, Purwokerto.

EPPO. 2007. Xanthomonas oryzae. Buletin OEPP/ EPPO 37: 543-553.

Fahy PC \& Hayward AC. 1983. Media and methods for isolation and diagnostic test. Pp. 337-378. In: P.C. Fahy and G.J. Persley (Eds.), Plant Bacterial Disease. Academic Press, London.

Goto M. 1992. Fundamentals of Bacterial Plant Pathology. Academic Press, Tokyo.

Gupta VS, Rajebhosale MD, Sodhi M, Singh S, Gnanamanickam SS, Dhaliwal HS, \& PK Ranjekar. 2001. Assessment of genetic variability and strain identification of Xanthomonas oryzae pv. oryzae Using RAPD-PCR and IS1112-based PCR. Current Science 80: 1043-1049.
Husodo SY. 2004. Swasembada beras masih labil. (On line) http://www.kapan lagi.com/h/ 0000039194.html. Diakses tanggal 5 Januari 2007.

IRRI. 2003. Bacterial leaf blight. (On line) http:// www.knowledgebank.irri.org/ riceDoctor_MX/ $\mathrm{F}$ a c t $-\mathrm{S}$ h e e t $\mathrm{s} / \mathrm{D}$ i s e a s e s / Bacterial_Leaf_Blight.htm. Diakses tanggal 2 Januari 2007.

Kadir TS. 1999. Variasi patogen Xanthomonas oryzae pv. oryzae. Prosiding Kongres Nasional XV dan Seminar Ilmiah PFI, Purwokerto, 16-18 September 1999.

Keller B, Feuillet C \& Messmer M. 2000. Basic Conceps and Application in Resistance Breeding. Pp. 101-160 In: Slusarenko AJ, Fraser RSS, van Loon LC, eds. Mechanisms of Resistance to Plant Diseases. Kluwer Academic Publisher. London.

Khan TUZ, Yasin SI, Ayub M, Shah JA \& Ahmad M. 2005. Effect of different chemicals and antibiotics on bacterial leaf blight (Xanthomonas oryzae pv. oryzae) of rice. Mycopath 3: 57-59.

Lee KS, Rasabandith S, Angeles ER \& Khush GS. 2003. Inheritance of resistance to bacterial blight in 21 cultivars of rice. Phytopathology 93: 147-152.

Lelliot RA \& Stead DE. 1987. Methods for the Diagnosis of Bacterial Diseases of Plants. British Society for Plant Pathology by Blackwell Scientific Publications, Melbourne.

Liu DN, Ronald PC \& Bogdanove AJ. 2006. Xanthomonas oryzae pathovars: model pathogens of a model crop. Molecular Plant Pathology 7: 303-324.

Moffett MJ \& Croft BJ. 1983. Xanthomonas. Pp. 189228 In: Fahy PC \& Persley GJ, eds. Plant Bacterial Diseases. Academic Press, London.

Mundt CC, Ahmed HU, Finckhn MR, Nieva LP \& Alfonso RF. 1999. Primary disease gradients of bacterial blight of rice. Phytopathology 89: 6467. 
Papanek CC. 2005. Budidaya Tanaman Padi. (Online). http://distan.gorotanloprov. go.id/agronomi/ komiditi_tanaman_pangan/budidaya\%20padi.pdf. Diakses tanggal 10 Oktober 2008.

Prakoso B. 2003. Detection and quantification of genetically modified soybean in tempe. Dissertation. Asian Institute of Technology Bangkok.

Prihatiningsih N \& Djatmiko HA. 2001. Eksistensi jamur patogen dan filoplan pada tanaman padi akibat perlakuan fungisida serta pengaruhnya terhadap penyelamatan produksi. Prosiding Kongres Nasional XVI dan Seminar Ilmiah PFI, Bogor, 22-24 Agustus 2001.

Reddy APK, MacKenzie DR, Rouse DI \& Rao AV. 1979. Relationship of bacterial leaf blight severity to grain yield of rice. The American Phytopathological Society 69: 967-969.

Rudolp K, Roy MA, Sasser M, Stead DE, Davis M, Swings J \& Gossele F. 1990. Isolation of bacteria. Pp. 45-86 In: Klement Z, Rudolp K \& Sands DC, eds. Methods in Phytobacteriology. Akodemial Kiado, Budapest.

Sands DC. 1990. Physiological criteria-determinative test. Pp. 133-143 In: Klement Z, Rudolph K \& Sands DC, eds, Methods in Phytobacteriology. Akodemial Akodemial Kiado, Budapest.

Schaad NW, Jones JB \& Lacy GH. 2001. Xanthomonas. Pp. 175-200 In: Schaad NW, Jones JB \& Chun W, eds. Laboratory Guide For Identification of Plant Pathogenic Bacteria. APS Press, St. Paul. Minnesota.
Srinivasan B \& Gnanamanickam SS. 2005. Identification of a new source of resistance in wild rice, Oryza rufipogon to bacterial blight of rice caused by Indian strain of Xanthomonas oryzae pv. oryzae. Current science 88: 12291231.

Sudir. 2009. Struktur patotipe Xanthomonas oryzae pv. oryzae pada stadium tumbuh berbeda beberapa varietas. Hlm. 421-429 Dalam: Suprihatno B et al., eds. Prosiding Seminar Nasional Padi, Balai Besar Penelitian Tanaman Padi tahun 2009.

Sudir \& Abdulrachman S. 2009. Pengaruh pupuk terhadap penyakit hawar daun bakteri Xanthomonas oryzae pv. oryzae pada varietas padi unggul baru, tipe baru, dan hibrida. Hlm. 431441 Dalam: Suprihatno B et al., eds. Prosiding Seminar Nasional Padi, Balai Besar Penelitian Tanaman Padi tahun 2009.

Suparyono, Sudir \& Suprihanto. 2004. Pathotype profile of Xanthomonas oryzae pv. oryzae isolates from the rice Ecosystem in java. Indonesian Journal of Agriculture Science 5: 63-69.

Tjubarjat T, Kadir TS \& Sumadi E. 1999. Skrining varietas terhadap hawar daun bakteri. Prosiding Kongres Nasional XV dan Seminar Ilmiah PFI, Purwokerto, 16-18 September 1999.

Yashitola J, Krishnaveni D, Reddy APK \& Sonti RV. 1997. Genetic diversity within the population of Xanthomonas oryzae pv. oryzae in India. Phytopathology 87: 760-765.

Yasin SI, Khan TUZ, Ayub M, Shah JA \& Anwar M. 2005. Economic evaluation of bacterial leaf blight (Xanthomonas oryzae pv. oryzae) disease of rice. Mycopath 3: 65-67. 